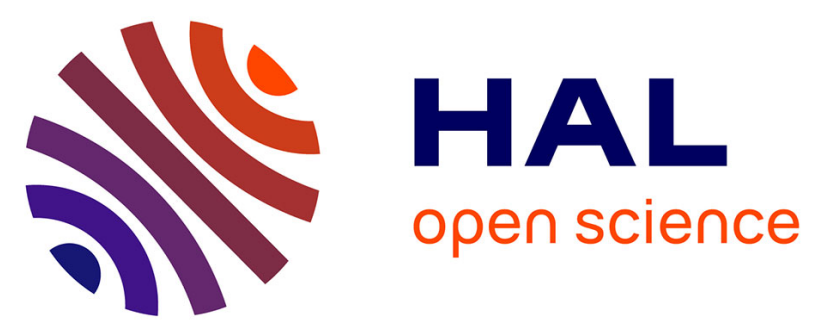

\title{
Chemotaxonomic discrimination of lichen species using an infrared chalcogenide fibre optic sensor: A useful tool for on-field biosourcing
}

M. Le Corvec, Catherine Boussard-Plédel, F. Charpentier, N. Fatih, B. Le Dare, F. Massart, F. Rojas, H. Tariel, Olivier Loréal, B. Bureau, et al.

\section{To cite this version:}

M. Le Corvec, Catherine Boussard-Plédel, F. Charpentier, N. Fatih, B. Le Dare, et al.. Chemotaxonomic discrimination of lichen species using an infrared chalcogenide fibre optic sensor: A useful tool for on-field biosourcing. RSC Advances, 2016, 6 (110), pp.108187-108195. 10.1039/c6ra17140k . hal-01416443

HAL Id: hal-01416443

https://hal-univ-rennes1.archives-ouvertes.fr/hal-01416443

Submitted on 24 Feb 2017

HAL is a multi-disciplinary open access archive for the deposit and dissemination of scientific research documents, whether they are published or not. The documents may come from teaching and research institutions in France or abroad, or from public or private research centers.
L'archive ouverte pluridisciplinaire HAL, est destinée au dépôt et à la diffusion de documents scientifiques de niveau recherche, publiés ou non, émanant des établissements d'enseignement et de recherche français ou étrangers, des laboratoires publics ou privés. 


\section{Chemotaxonomic discrimination of lichens species using infrared chalcogenide fibre optic sensor: a useful tool for on-field biosourcing.}

M. Le Corvec, ${ }^{\text {ab }}$ C. Boussard-Plédel, ${ }^{c}$ F.Charpentier, ${ }^{b}$ N. Fatih, ${ }^{b}$ B. Le Dare, ${ }^{d}$ F. Massart, ${ }^{d}$ F. Rojas, ${ }^{c}$ H. Tariel, ${ }^{b}$ O. Loréal, ${ }^{e}$ B. Bureau, ${ }^{c}$ J. Boustie, ${ }^{d}$ O.Sire ${ }^{a}$ and F. Lohézic - Le Dévéhat ${ }^{d, *}$

Abstract: Many analytical methods are known to discriminate natural products based on the set of chemical compounds they contain. Here, we evaluated the ability of the Fibre Evanescent Wave Spectroscopy (FEWS) to discriminate lichen natural extracts. Ten species of lichens including four chlorolichens (three Cladonia species and Stereocaulon scutelligerum), three tripartite lichens (Stereocaulon species) and three cyanolichens (Lichina pygmaea, Collema cristatum, Peltigera membranacea) belonging to six genera and six families were studied. One macroscopic cyanobacterium (Nostoc sp.), corresponding to the photobiont partner of Peltigera and Collema cyanolichens, was included for comparison. MIR spectra were acquired from lichens organic extracts between $3800-950 \mathrm{~cm}^{-1}$ using a chalcogenide infrared fibre optical device. Principal Component Analysis (PCA) and PCA-LDA (PCA-Linear Discriminant Analysis) based on the concept of variable clustering has been applied to absorbance MIR second derivative spectra for classification of the 11 species. The method succeeded in separating all lichen species and in identifying the major compounds. Moreover the signature of the sample was specific of each lichen suggesting that minor compounds played a role. Our data showed that FEWS optical sensor profiling is a rapid, efficient and convenient tool for metabolic profiling and suggest that it can be used: i) in chemotaxonomic approaches, ii) in processes for certification requirements in active compounds availability, and iii) in identifying new biosourcings in so far non investigated lichen species. 


\section{Introduction}

Lichens like corals and mycorrhiza are symbiotic organisms including a photosynthetic partner and saprophytic fungi mostly belonging to Ascomycetes. When the photosymbiont is a green alga, the lichen is called chlorolichen while it is called cyanolichen when they accommodate cyanobacteria. An additional photosymbiont to a primary one indicates tripartite lichen. This mutualistic exchange allowed them to live in extreme environments (Antarctic, desert,...) thanks to the biosynthesis via acetyl polymalonyl, shikimate and mevalonate pathways of various families of compounds such as depsides, depsidones, dibenzofurans, aliphatic acids, anthraquinones, pulvinic acids, mycosporines, xanthones and terpenoids ${ }^{1}$. In most cases, the cyanolichens contain hydrophilic compounds (mycosporines and mycosporines-like amino acids) while the phenolic metabolites resulting from the polymalonyl pathway are more specific of tripartite and chlorolichens. These polyphenolic compounds (depsides, depsidones, dibenzofurans) exhibited very interesting biological activities ${ }^{2 ;}{ }^{3}$. In the last century, the dibenzofuran usnic acid has been largely studied for various antimicrobial properties ${ }^{4}$. More recently, some new biological targets revealed the potentialities of lichen compounds: some depside (perlatolic acid) and depsidone (physodic acid) showed anti-inflammatory activities by inhibiting mPGEs1 (microsomal prostaglandin E synthase-1) ${ }^{5 ;}$, atranorin and derivatives (depsides) inhibited the hepatitis $C$ virus ${ }^{7}$; protolichesterinic acid was patented for its depigmenting activities ${ }^{8}$, lobaric acid and derivatives inhibited PTP1B (Tyrosine-protein phosphatase nonreceptor type 1 ) suggesting a role in type 2 diabetes ${ }^{9}$. Until now, 1054 lichen compounds have been characterized and new ones are regularly discovered ${ }^{1 ;}$

${ }^{10}$. So, it is of interest to develop new methods in aim of profiling lichens for their chemical composition. In this objective, the potential of numerous methods has been evaluated on lichens like LC-MS ${ }^{11}$, LDI-MS ${ }^{12}$, Raman spectroscopy ${ }^{13-15}$. Here, we propose a method based on mid infrared (MIR) spectroscopy. Infrared spectroscopy is commonly used for identification of molecular functional groups. The mid-infrared spectrum ranges from 4000 to $400 \mathrm{~cm}^{-1}(2.5 \mu \mathrm{m}$ to 25 $\mu \mathrm{m})$ which embed most of the fundamental vibrations of the molecular functional groups which is useful to fingerprint molecules ${ }^{17}$. As lichens are bioindicators ${ }^{18 ;}$ 19, MIR spectral analyses have been performed to estimate air pollution. Indeed, lichens exposed to ammonia, nitric acid vapour or sulphuric acid displayed new IR absorption bands which were assigned to the de novo synthesis of new compounds within the lichen thallus ${ }^{20 ; 21}$. Moreover, some assigned marker IR bands have been used to monitor environmental stresses (UV-exposure, desiccation, low temperatures) ${ }^{13}$; 14. Here, chalcogenide glass optical fibres, with a transparency in the 4000 to $850 \mathrm{~cm}^{-1}$ domain, are used to collect MIR spectra of lichens organic extracts. The principle of the fibre evanescent wave spectroscopy (FEWS) is based on the general concept of ATR but the use of a fibre permits to increase the number of total internal reflections ${ }^{22}$ and their hydrophobic nature makes them less sensitive to water which often screens the contribution of molecules of interest. This technology has been successfully applied to analyse food contamination ${ }^{23}$, for the monitoring of bacterial biofilms ${ }^{24}$, for the study of biological complex samples like serum ${ }^{25 ;} 26$ and more recently FEWS was demonstrated to be useful for quick identification of septic arthritis by studying synovial fluid ${ }^{27}$.

We propose here to use infrared FEWS combined with adequate statistical analysis to fingerprint lichen samples representative of vegetal and fungi materials. We demonstrate that this method can allow for a rapid identification of known compounds present in a mixture and helping thereby the discovery of new biosourcings. Moreover, as natural compounds are usually characterized by their chemical signature, this technique can be helpful for quality control by providing an analytical validation of raw materials.

\section{Materials and methods}

\subsection{Lichen samples collection}

Ten lichens and one cyanobacterium were collected in France but also in the Reunion Island and Italy (Table 1, Figure 2S-supplementary data). Four contained chlorococcoid algae (Stereocaulon scutelligerum, Cladonia convoluta, C. rangiferina, C. portentosa) and three contained only cyanobacteria, two of these belonging to the Nostoc genus (Collema cristatum var. marginale, Peltigera membranacea) and one to Calothrix (Lichina pygmaea). The three remaining lichen species (Stereocaulon evolutum, S. vesuvianum, $S$. vulcani) contained chlorococcoid algae and additional cyanobacteria in cephalodia. One macroscopic cyanobacterium (Nostoc sp.), corresponding to the photobiont partner of Peltigera and Collema cyanolichens, was included for comparison. After identification by Harrie Sipman for Stereocaulon vulcani and S. scutelligerum and the 
others by Claude Roux, the specimens set was deposited at the Herbarium of the Department of Pharmacognosy and Mycology of Rennes with reference numbers (Table 1 ).

\subsection{Chemicals and reagents}

All chemicals (acetonitrile, chloroform, methanol, tetrahydrofuran, toluene, ethyl acetate, formic acid) were of analytical reagent grade and were purchased from Sigma (St Quentin-Fallavier, France). Authentic atranorin, lobaric acid and stictic acid, (+)-usnic acid were previously isolated from Stereocaulon halei ${ }^{28}$ and Usnea articulata

29 , respectively. Norstictic acid, fumarprotocetraric acid and perlatolic acid were available in the laboratory under the codes $\mathrm{JB} / \mathrm{A} / 036, \mathrm{JB} / \mathrm{A} / 003 \mathrm{a}, \mathrm{JB} / \mathrm{A} / 130$, respectively.

\subsection{Extraction of lichen samples}

Ten replicates of whole thalli ( $250 \mathrm{mg}$ each) were powdered for each species and $6 \mathrm{~mL}$ of a mixture chloroform/methanol (2/1) were added in each tube. Extraction was performed using a Heidolph Synthesis ${ }^{\circledR}$ apparatus during 2 hours at room temperature to avoid any methanolysis reaction under stirring $(1,000 \mathrm{rpm})$. This operation was repeated three times and filtrates were pooled to yield the organic extracts which were then evaporated, weighed and stored under nitrogen. For each sample the weight ratio of secondary metabolites is calculated as the ratio between the dried organic extract and the lichen powder.

\subsection{Preparation of sample solutions}

All dried organic samples were re-dissolved in chloroform/methanol $(1 / 1)$ to reach a concentration of $100 \mathrm{mg} \cdot \mathrm{mL}^{-1}$, centrifuged $(3,000$ rpm for 5 minutes). The supernatant was evaporated and weighed to allow the preparation of organic solutions in chloroform/methanol (1/1) at $10 \mathrm{mg} \cdot \mathrm{mL}^{-1}$.

\subsection{Chalcogenide infrared optical fibres}

The MIR spectra were collected using a Fourier Transform Infrared Spectrophotometer (Bruker T27) coupled with a chalcogenide optical fibre (Figure 1). The principle of the measurement is based on the evanescent wave spectroscopy. The light emitted by the black body source of the spectrometer is injected at the input of the fibre and collected at the output by a cooled MCT detector. The sensing part of the fibre in contact with the organic solution is shaped in a looping head having a diameter equal to $2 \mathrm{~mm}$. This design permits to increase the sensitivity of the sensor by multiplying the number of reflexions in the fibre ${ }^{17}$. The reference spectrum is collected against air. Then, $10 \mu \mathrm{L}$ of solution are deposited on the loop of the fibre and the signal is recorded after 2 min. Every single beam spectrum is the average of 100 scans collected within about $2 \mathrm{~min}$. Between two measurements, the fibre loop is cleaned by immersion for $10 \mathrm{~s}$ in an ultrasonic bath filled with water in which 2 drops of RBS- $25^{\mathrm{TM}}$ (Carl Roth, Karlsruhe, Germany) have been added. Then, the fibre is rinsed two times with distilled water and dried with an absorbing paper. The signal amplitude is checked before each new measurement

\subsection{Treatments and analysis of Infrared spectra}

For each sample, ten measurements were achieved corresponding to each replicate. The spectra of two pure compounds, atranorin and stictic acid were also recorded. MIR spectra were preprocessed and analysed in the $3800-950 \mathrm{~cm}^{-1}$ frequency domain, where most of the biomolecules show up. Raw spectra were preprocessed using Extended Multiplicative Signal Correction (EMSC) for baseline correction and normalization. Second derivatives of spectra were also calculated, smoothed using a 13-points SavitzkyGolay smoothing algorithm, and normalized by vector normalization over the whole spectral range. Second derivatives were obtained after elimination of the contribution of environmental $\mathrm{CO}_{2}$ by generation of a straight-line from 2800 to $1800 \mathrm{~cm}^{-1}$. Quality test was applied to eliminate spectra that exhibit low $\mathrm{S} / \mathrm{N}$ ratio.

\subsection{Reproducibility}

The reproducibility of the optical sensors was assessed by achieving thirty measurements of a unique organic sample of Stereocaulon scutelligerum $\left(10 \mathrm{mg}^{-\mathrm{mL}^{-1}}\right)$, which were recorded with two distinct fibres.

\subsection{Statistical analysis of Infrared spectra}

Two methods were used for spectra analysis. Firstly, a Principal Component Analysis (PCA) (unsupervised method) was used to extract the important information from the data matrix and to feature the pattern of similarity between the observations and the variables by displaying them as a factorial map ${ }^{30}$. Secondly, a supervised method, linear discriminant analysis (PCA-LDA), was used to discriminate species. LDA was used to classify the lichens species, but this method requires fewer spectral variables than samples per group. So it was necessary to reduce the dimension of the spectral data set by previously performing a PCA. The population of lichens was split in two sub-groups, i.e. calibration (7 to 8 spectra of each species) for model construction and validation (1 or 2 spectra of each species) to evaluate the performance of the model.

\subsection{High performance thin layer chromatography (HPTLC)}

Two $\mu \mathrm{L}$ of the organic samples $\left(10 \mathrm{mg} \cdot \mathrm{mL}^{-1}\right.$ ) were spotted using an automated sample applicator, CAMAG ATS-4 on HPTLC plates 
(Merck silica gel 60F254) and a densitometric UV scanner CAMAG Scanner type 3 was used for plate analysis (CAMAG, Muttenz, Switzerland). Both instruments were controlled by the Wincats software V1.4.3. After migration in the solvent (toluene/ethyl acetate/formic acid $(139 / 83 / 8)$ ), plates were scanned at 6 wavelengths $220,260,280,310,340$ and $370 \mathrm{~nm}$. Then, they were revealed by specific reagents as anisaldehyde- $\mathrm{H}_{2} \mathrm{SO}_{4}$ to dye the lichen's secondary metabolites.

\section{Results and discussion}

\subsection{Metabolite profiling of the lichen samples}

A representative panel of the three symbiotic forms found among lichens (and so of the metabolites they contain) was selected for the study: four chlorolichens, three cyanolichens and three tripartite species. A macroscopic cyanobacterium was also included in this panel as representative of the cyanobiont of the cyanolichens Peltigera membranacea and Collema cristatum. The dried organic extracts of these eleven species allowed calculation of an extraction yield which reflects the amount of secondary metabolites. The combination of organic solvents was also chosen to extract a large variety of secondary metabolites. The extraction weight ratio varied between 2 and $12 \%$. The best and the lowest extraction weight ratio were observed with the cyanolichens Peltigera membranacea (12\%), Collema cristatum and Lichina pygmaea (2\%) (Figure 1S-supplementary data). No correlation between the content in secondary metabolites and the nature of the photobiont present in the thalli was observed.

These organic extracts were spotted on TLC plates and exhibited a large panel of secondary metabolites as revealed under UV then after spraying the plates with the sulphuric anisaldehyde reagent (Figure 2). Standards available in the lab (atranorin, fumarprotocetraric acid, norstictic acid, perlatolic acid, stictic acid, usnic acid) were compared to the lichen extracts and confirmed their presence for Cladonia species ${ }^{12 ; 31 ; 32}$ and Stereocaulon species ${ }^{33}$. Some lichens exhibited similar metabolic profiles like S. vulcani and $S$. vesuvianum whose major compounds were atranorin and stictic acid (Figure 3). The three cyanolichens and the cyanobacterium showed also similar profiles.

Some distinct species produce same metabolites. Cladonia convoluta and Cladonia portentosa both synthetize usnic acid, C. convoluta and $\mathrm{C}$. rangiferina have in common fumarprotocetraric acid while all Stereocaulon species synthetize atranorin as a major compound (Figure 2 and Figure 3 ). If $C$. convoluta was easy to discriminate from both other Cladonia species through their contrasted morphological appearance (Figure 2S-supplementary data); this was not the case for two Stereocaulon species, S. vulcani and S. vesuvianum (Figure 4). Moreover, for these latter species, HPTLC-UV profile of secondary metabolites is not fully conclusive to differentiate them (Figure 2).

\subsection{FT-IR spectral data}

The MIR spectra of the lichen extracts (10 replicates for each species) and two pure metabolites (stictic acid and atranorin) were acquired at the same concentration $\left(10 \mathrm{mg} \cdot \mathrm{mL}^{-1}\right)$. Analyses were performed in the $3200-2800 \mathrm{~cm}^{-1}$ and $1800-950 \mathrm{~cm}^{-1}$ domains. As shown in Figure $5 \mathrm{a}$, which displayed the spectra of three species, the $3200-2800$ domain is dominated by three peaks at 2958, 2923 and $2852 \mathrm{~cm}^{-1}$ which correspond to $v \quad v \quad$ and $v\left(\mathrm{CH}_{2}\right)$, respectively. In opposite, the $1800-950 \mathrm{~cm}^{-1}$ domain, exhibited large differences between species. Numerous absorption bands show up in this frequency domain which concerns all biochemical classes: lipids, proteins and sugars. To enhance the separation of overlapping peaks ${ }^{34}$, second derivative spectroscopy was applied to increase the spectral resolution (Figure 5b).

\subsection{Reproducibility}

Spectra exhibiting low $\mathrm{S} / \mathrm{N}$ ratio (two and four for fibre 1 and 2, respectively) were discarded.

A PCA was processed in the $3200-2800,1800-950 \mathrm{~cm}^{-1}$ spectral range. Statistical tests in the two first principal components, which represented $87 \%$ of the total variance, revealed no difference $(p<0.05)$ between the fibres (Figure 3S-supplementary DATA).

\subsection{Distinction between species}

Due to the complexity of spectral data reflecting the sample's molecular composition, multivariate analysis was used to discriminate the lichen samples. At first, PCA was used to explore the structure of second derivative spectra. The PCA scores plot from the $1800-950 \mathrm{~cm}^{-1}$ infrared region (Figure 6) showed the low variance of replicates. An efficient inter species discrimination is attained from the two first components (PC1 and PC2), which features up to $49 \%$ of the total variance. This observation highlights that the inter-species variability is larger than the variability inside species clusters. The PC1 best discriminates Cladonia convoluta and Cladonia portentosa from all other investigated species whereas PC2 discriminates cyanolichens except Peltigera membranacea. Nevertheless, the cyanolichens and Nostoc were clearly separated from the chlorolichens and tripartite lichens. None of the 7 first PCs allows for isolating chlorolichens from the tripartite lichens suggesting that, despite different morphological typologies, they share similar secondary metabolites panels.

Then, PCA-LDA was used to classify the species. The classification model was set up from $80 \%$ of the samples (calibration). The remaining $20 \%$ (validation) were submitted to prediction in order to evaluate the model's performance. The best results were obtained from the $1800-950 \mathrm{~cm}^{-1}$ domain with 4 components. The model allowed a classification performance of $100 \%$ (Table 1Ssupplementary data). In validation, the classificatory discriminant analysis indicated correct classification except for Collema cristatum spectra which were classified in the Nostoc group (Table 2Ssupplementary data). This result was consistent with what is observed in Figure 6. Indeed the cyanolichens Collema cristatum and Lichina pygmea and the cyanobacterium Nostoc exhibited close 
PCA scores suggesting that the metabolites extracted from these three species are similar. Thus, these results demonstrate that MIR spectra can discriminate lichens species within families and genera. Our results well match those reported by Alcantara ${ }^{35}$ who compared the FTIR spectral data of 11 lichen species and discriminate them at a species level. Nevertheless, their analyses were performed on lichen powders using $\mathrm{KBr}$ pellets. As a consequence, their analyses were mainly based on carbohydrates signals, specifically on polyols and monosaccharides which amounts are much higher than the secondary metabolites of interest on which our analyses are based on.

\subsection{Major compounds identification from MIR spectra}

In order to identify the major compounds present in the lichen extracts from MIR spectra $\left(1800-950 \mathrm{~cm}^{-1}\right)$, three major secondary metabolites usnic acid, atranorin and stictic acid were selected and compared to the spectra of four lichen extracts i.e. Cladonia portentosa, Cladonia convoluta, Stereocaulon vesuvianum and Stereocaulon vulcani. As discussed previously, Figure 6 showed that Cladonia convoluta and Cladonia portentosa exhibited high PC1 scores. This indicated that this $\mathrm{PC}$ reflected a prominent variability between the extracted metabolites. By HPTLC, usnic acid was identified as the main metabolite extracted from these two species (Figure 2). The PC1 main loadings were located at 1627, 1369, 1288, 1187, 1143, 1118, 1068 and $1037 \mathrm{~cm}^{-1}$ (Figure 7a). These peaks fitted well the main usnic acid spectral peaks assigned in a spectral bank ${ }^{37}$. Moreover, Liao et al ${ }^{16}$ used the peak at $1191 \mathrm{~cm}^{-1}$ as a marker of usnic acid in lichens for imaging technology. From this result, it is suggested that the PC1 largely matches the signature of usnic acid. To evidence other metabolites, a PCA was achieved on the $1800-950 \mathrm{~cm}^{-1}$ domain with the remainder lichens to exclude the variability assigned to high usnic acid contents, hence by excluding Cladonia convoluta and Cladonia portentosa samples. Once the factorial map was established (Figure 8), the MIR spectra of atranorin and stictic acid, both main metabolites revealed by HPTLC in S. vesuvianum and S. vulcani (Figure 2), were spotted on the map. PC1 allowed discriminating S. vulcani from other lichen samples and the PC1 scores of second metabolites along the PC1 axis showed that stictic acid was located close to $S$. vulcani while PCA score of atranorin was very close to $S$. vesuvianum. This result strongly suggests that the main metabolite extracted from $S$. vulcani was stictic acid and that the PC1 primarily features the spectral signature of stictic acid in lichens extracts as evidenced from the corresponding second derivative spectra (Figure $7 \mathrm{~b}$ ). The main metabolites extracted from $S$. vesuvianum are atranorin and stictic acid but the PCA scores plot (Figure 8) and the derivative spectra suggested that $S$. vesuvianum infrared spectra was dominated by atranorin (Figure 7c). It is important to note that none of the first PCs discriminated atranorin however it is worth noticing that some spectral domains differed between metabolites and the species so suggesting that distinct compounds were also synthesized by these two species. Thus, even if $S$. vulcani and $S$. vesuvianum exhibit close HPTC-UV profiles, infrared analyses permitted to distinguish them. Hence MIR spectroscopy appears to be more discriminant than planar chromatography (Figure 2).

\section{Conclusion}

In conclusion, our results suggest that the feasibility of profiling lichen samples by IR-FEWS is assessed. This is critical since chemotaxonomic of lichens is particular complex and very few scientists are trained for such discriminations. Indeed, the major compounds (the so-called secondary metabolites) can be easily identified with this technology. Moreover, as major secondary metabolites are critical for lichen species identification, this method can differentiate them quickly and ambiguities in species identification can be reliably resolved. Thus, IR-FEWS can be considered as a predictable chemotaxonomic tool. This first assay on fungal and algal material with lichen sample is conclusive and need to be tested on other natural organisms like plant materials. Through this, IR-FEWS could be used in various domains such as food processing to check the identity of raw material particularly since the technology is available now "on the field". Such a technology could be of great interest to solve a current paradox that is an ever increasing effort to screen organisms for the quest of new bio-active molecules concomitant with a somehow rapid decrease in taxonomy experts who sole can reliably identify complex species like lichens. Hence, biochemical profiling is critical as an unsupervised tool fitted to on-field rapidly screen of known biosourcings for their contents of molecules of interest or unreferenced organisms for their potential to synthesize a particular bioactive molecule. The design apparatus has now evolved in order to provider convenient disposable optical sensors which avoids sample cross-contamination and allows unbiased baseline correction. All together, these unique technical specifications (large spectral window, fast data collection, unbiased spectral reference, accompanying statistical data treatment, equipment portability) provide a unique global solution to conveniently screen new species, new biomolecules which are hardly needed by ever growing green biotechnologies.

\section{Acknowledgements}

We thank Marylène Chollet and Nina Corlay for providing Peltigera membranacea, S. vulcani and S. scutelligerum. The authors thank the ANRT for the grant that supported Maëna Le Corvec.

\section{References}

1 E. Stocker-Wörgötter, Nat. Prod. Rep, 2008, 24, 188-200.

2 K. Muller, Appl Microbiol Biotechnol, 2001, 56, 9-16. 
3 J. Boustie and M. Grube, Plant Genet Resour, 2005, 3, 273287.

4 G. Shrestha and L. L. St. Clair, Phytochem Rev, 2013, 12, 229244.

5 J. Bauer, B. Waltenberger, S. Noha, D. Schuster, J. Rollinger, J. Boustie, M. Chollet, H. Stuppner and O. Werz, ChemMedChem, 2012, 7, 2077-2081.

6 S. K. Oettl, J. Gerstmeier, S. Y. Khan, K. Wiechmann, J. Bauer, A. G. Atanasov, C. Malainer, E. M. Awad, P. Uhrin, E. H. Heiss, B. Waltenberger, D. Remias, J. M. Breuss, J. Boustie, V. M. Dirsch, H. Stuppner, O. Werz and J. M. Rollinger, PLOSone, 2013, DOI: 10.1371/journal.pone.0076929.

7 T. H. Vu, A.-C. Le Lamer, C. Lalli, J. Boustie, M. Samson, F. Lohézic-Le Dévéhat and J. Le Seyec, PLOSone, 2015, DOI: 10.1371/journal.pone.0120405.

8 J. Boustie, M. Galibert, F. Lohezic, M. Chollet-Krugler, S. Tomasi and B. Legouin-Gargadennec, Acide lichesterinique et ses dérivés comme inhibiteurs de la pigmentation, 2013, PCT Int. Appl. Depot INPI NFR 12.53585, WO 2013156738 A2 20131024.

9 C. Seo, J. Sohn, J. Ahn, J. Yim, H. Lee and H. Oh, Bioorg Med Chem Lett, 2009, 19, 2801-2803.

10 P. Le Pogam, A. Le Lamer, B. Siva, B. Legouin, A. Bondon, J. Graton, D. Jacquemin, I. Rouaud, S. Ferron, W. Obermayer, K. Babu and J. Boustie, J Nat Prod, 2016, DOI: 10.1021/acs.jnatprod.5b01073.

11 D. Parrot, T. Peresse, E. Hitti, D. Carrie, M. Grube and S. Tomasi, Phytochem Anal, 2015, 26, 23-33.

12 P. Le Pogam, A. Schinkovitz, B. Legouin, A. Le Lamer, J. Boustie and P. Richomme, Anal Chem, 2015, 87, 1042110428.

13 H. Edwards, E. Newton, D. Wynn-Williams and S. Coombes, J Mol Struct, 2003, 648, 49-59.

14 H. Edwards, E. Newton and D. Wynn-Williams, J Mol Struct, 2003, 651-653, 27-37.

15 H. Edwards, E. Newton, D. Wynn-Williams and R. LewisSmith, Spectrochimica Acta Part A, 2003, 59, 23012309.

16 C. Liao, M. Piercey-Normore, J. Sorensen and K. Gough, Analyst, 2010, 135, 3242-3248.

17 D. Ellis and R. Goodacre, Analyst, 2006, 131, 875-885.

18 J. Shao, J. Shi, B. Duo, C. Liu, Y. Gao, J. Fu, R. Yang, Y. Cai and G. Jiang, RSC Adv, 2016, 6, 541-546.

19 A. Pino, A. Alimonti, M. Conti and B. Bocca, J Environ Monit, 2010, 12, 1857-1863.

20 A. Meisurova, S. Khizhnyak and P. Pakhomov, J Appl Spectrosc, 2009, 76, 420-429.

21 A. Meysurova, S. Khizhnyak and P. Pakhomov, J Appl Spectrosc, 2011, 78, 711-718.

22 P. Houizot, M. Anne, C. Boussard-Plédel, O. Loréal, H. Tariel, J. Lucas and B. B, Sensors, 2014, 14, 17905-17914.

23 M. Brandily, V. Monbet, B. Bureau, C. Boussard-Plédel, O. Loréal, J. Adam and O. Sire, Sens. Actuators B Chem, 2011, 160, 202-206.

24 J. Keirsse, B. Bureau, C. Boussard-Pledel, M. R. Leroyer, P, V. Dupont, M. Anne, C. Ribault, O. Sire, O. Loreal and J.
Adam, (ed. A. G. M. a. R. R. B. Culshaw), 2004, pp. 6168.

25 M. Anne, C. Le Lan, V. Monbet, C. Boussard-Plédel, M. Ropert, O. Sire, M. Pouchard, C. Jard, J. Lucas, J. Adam, P. Brissot, B. Bureau and O. Loréal, J Biomed Opt, 2009, 14, 054033.

26 P. Lucas, D. Le Coq, C. Juncker, J. Collier, D. Boesewetter, C. Boussard-Pletel, B. Biureau and M. Riley, Appl Spectrosc, 2005, 59, 1-9.

27 J. Albert, V. Monbet, A. Jolivet-Gougeon, N. Fatih, M. Le Corvec, M. Seck, F. Charpentier, G. Coiffier, C. Boussard-Pledel, B. Bureau, P. Guggenbuhl and $\mathrm{O}$. Loréal, Joint Bone Spine, 2015.

28 F. Ismed, F. Lohézic-Le Dévéhat, O. Delalande, S. Sinbandhit, A. Bakhtiar and J. Boustie, Fitoterapia, 2012, 83, 1693 1698.

29 F. Lohézic - Le Dévéhat, S. Tomasi, J. Elix, A. Bernard, I. Rouaud and P. Uriac, J Nat Prod, 2007, 70, 1218-20.

30 L. Wang and B. Mizaikoff, Anal Bioanal Chem, 2008, 391, 1641-1654.

31 M. Kosanic, B. Rankovic, T. Stanojkovic, A. Rancic and N. Manojlovic, LWT-Food Sci Technol, 2014, 59, 518-525.

32 C. F. Culberson, W. L. Culberson and A. Johnson, Supplement to "Chemical and Botanical Guide to Lichen Products", vol. 2 (ed. A. B. a. L. Society), 1970, pp. 200.

33 M. Lamb, J Hattori Bot Lab, 1977, 43, 191-355.

34 L. Rieppo, S. Saarakkala, T. Närhi, H. J. Helminen, J. S. Jurvelin and J. Rieppo, Osteoarthr Cartil, 2012, 20, 451-459.

35 G. B. Alcantara, N. K. Honda, M. M. C. Ferreira and A. G. Ferreira, Anal Chim Acta, 2007, 595, 3-8.

36 SpectralDatabase, $\quad$ http://sdbs.db.aist.go.jp/sdbs/cgibin/direct frame top.cgi, 2016.

\section{Abbreviations}

ATR : Attenuated total reflection, EMSC : Extended Multiplicative Signal Correction, FEWS: Fibre Evanescent Wave Spectroscopy, FTIR: Fourier transform infrared spectroscopy, HPTLC: High Performance Thin Layer Chromatography, IR: infrared, LC-MS: Liquid Chromatography coupled to Mass Spectrometry, MIR: Middle Infrared, PC: , PCA-LDA: Principal Component Analysis and Linear Discriminant Analysis.

Keywords:

Lichen, natural product, vibrational spectroscopy, FEWS, Mid Infrared, chalcogenide fibre and sensor 
Table 1 Systematic list, sampling location, time collection and reference numbers of the lichen species / Nostoc sp. used for the study.

\begin{tabular}{|c|c|c|c|c|c|}
\hline & Lichen & Order & Family & Sampling site / altitude/ collection data & $\begin{array}{l}\text { Voucher } \\
\text { code }\end{array}$ \\
\hline Chlorolichen & Cladonia convoluta (Lam.)Cout. & Lecanorales & Cladoniaceae & $\begin{array}{l}\text { Cressensac, Lot (France), } 260 \text { m, September } \\
2012\end{array}$ & $\mathrm{JB} / 12 / 148$ \\
\hline Chlorolichen & Cladonia portentosa (Dufour)Coem. & Lecanorales & Cladoniaceae & $\begin{array}{l}\text { Cressensac, Lot (France), } 260 \text { m, November } \\
2005\end{array}$ & $\mathrm{JB} / 05 / 54$ \\
\hline Chlorolichen & Cladonia rangiferina (L.)Weber x.F.H.Wigg & Lecanorales & Cladoniaceae & $\begin{array}{l}\text { Lac Del Palm, Pyrénées (France), } 1500 \text { m, } \\
\text { August } 2002\end{array}$ & $\mathrm{JB} / 02 / 64$ \\
\hline Chlorolichen & Stereocaulon scutelligerum Th.Fr & Lecanorales & Stereocaulaceae & $\begin{array}{l}\text { Langevin valley, Reunion island, } 1000 \mathrm{~m} \text { high, } \\
\text { March } 2011\end{array}$ & $\mathrm{JB} / 11 / 123$ \\
\hline Tripartite lichen & Stereocaulon evolutum Graewe & Lecanorales & Stereocaulaceae & $\begin{array}{l}\text { Commana, Britanny, (France), } 260 \mathrm{~m} \text { high, } \\
\text { July } 2010\end{array}$ & $\mathrm{JB} / 10 / 121$ \\
\hline Tripartite lichen & Stereocaulon vesuvianum Pers & Lecanorales & Stereocaulaceae & $\begin{array}{l}\text { Etna, Sicilia island (Italia), } 1350 \mathrm{~m} \text { high, } \\
\text { August } 2001\end{array}$ & $\mathrm{JB} / 02 / 01$ \\
\hline Tripartite lichen & Stereocaulon vulcani (Bory)Ach. & Lecanorales & Stereocaulaceae & $\begin{array}{l}\text { Langevin valley, Reunion island, } 1000 \text { m high, } \\
\text { March } 2011\end{array}$ & $\mathrm{JB} / 11 / 122$ \\
\hline Cyanolichen & $\begin{array}{l}\text { Collema cristatum var.marginale (L.)Weber } \\
\text { x.F.H.Wigg }\end{array}$ & Peltigerales & Collemataceae & $\begin{array}{l}\text { Cressensac, Lot (France), } 260 \mathrm{~m} \text {, October } \\
2004\end{array}$ & $\mathrm{JB} / 04 / 31$ \\
\hline Cyanolichen & Lichina pygmaea (Lightf.)C.Agardh. & Lichinales & Lichinaceae & $\begin{array}{l}\text { Pointe de la Garde, Dinard (France), level of } \\
\text { sea, December } 2007\end{array}$ & $\mathrm{JB} / 07 / 98$ \\
\hline Cyanolichen & Peltigera membranacea (Ach.) Nyl. & Peltigerales & Peltigeraceae & $\begin{array}{l}\text { Les Glières, Savoie (France), } 1200 \text { m, August } \\
2011\end{array}$ & $\mathrm{JB} / 11 / 130$ \\
\hline Cyanobacterium & Nostoc sp. & Cyanobacteria & & $\begin{array}{l}\text { Betahon, Morbihan (France), level of sea, } \\
\text { January } 2012\end{array}$ & $\mathrm{JB} / 13 / 166$ \\
\hline
\end{tabular}


Figure 1: Schematic representation of the experimental set-up used for recording the mid-infrared spectra

Figure 2: TLC profile of the eleven organic samples in toluene/ethyl acetate/formic acid (139/83/8) after spraying sulfuricanisaldehyde and heating. Major secondary metabolites have been identified with comparison with standards (At : atranorin; Fu: fumarprotocetraric acid; Lob: lobaric acid ; Nor: norstictic acid ; Per: perlatolic acid; St : stictic acid ; Us : usnic acid).

* Means that the lichens are belonging to the cyanolichens, ${ }^{\circ}=$ tripartite lichens, $+=$ chlorolichens.

Figure 3: Structure of the major compounds of S. vulcani , S. vesuvianum, Cladonia portentosa and Cladonia convoluta

Figure 4: Morphology of Stereocaulon vesuvianum (a) and Stereocaulon vulcani (b)

Figure 5: a)EMSC corrected Infrared spectra in absorbance and b)second derivative for 3 species. Lichina pygmaea (black), Cladonia convoluta (dark grey) and S.evolutum (light grey).

Figure 6: PCA scores plot of second derivative spectra in the $1800-950 \mathrm{~cm}^{-1}$ domain of the different lichens species

Figure 7: a) Second derivative spectra of Cladonia convoluta (black), Cladonia portentosa (dark grey), and PC1 loadings (light grey); b) Second derivative spectra of S.vulcani (black), Stictic acid (dark grey), and PC1 loadings (light grey); c) Second derivative spectra of S.vesuvianum (black), and Atranorin (dark grey).

Figure 8: PCA scores plot of second derivative spectra in the $1800-950 \mathrm{~cm}^{-1}$ domain of the different lichens species without Cladonia convoluta and Cladonia portentosa.

Figure 1S: Extraction yields for the lichen samples. $250 \mathrm{mg}$ of ground lichen species were extracted with $6 \mathrm{~mL}$ of a mixture chloroform/methanol (2/1) during 2 hours at room temperature under stirring. This operation was repeated three times and filtrates were combined to give the organic extracts which were then evaporated to be weighed and stored under nitrogen. The extraction yield represents the ratio between the weight of the extract and the weight of the lichen powder.

Figure 2S: Morphology of the eleven species included in the study

Figure 3S: PCA scores plot of second derivative spectra in the $1800-950 \mathrm{~cm}^{-1}$ domain for the interfibre variability evaluation. The barycentre was represented with cross.

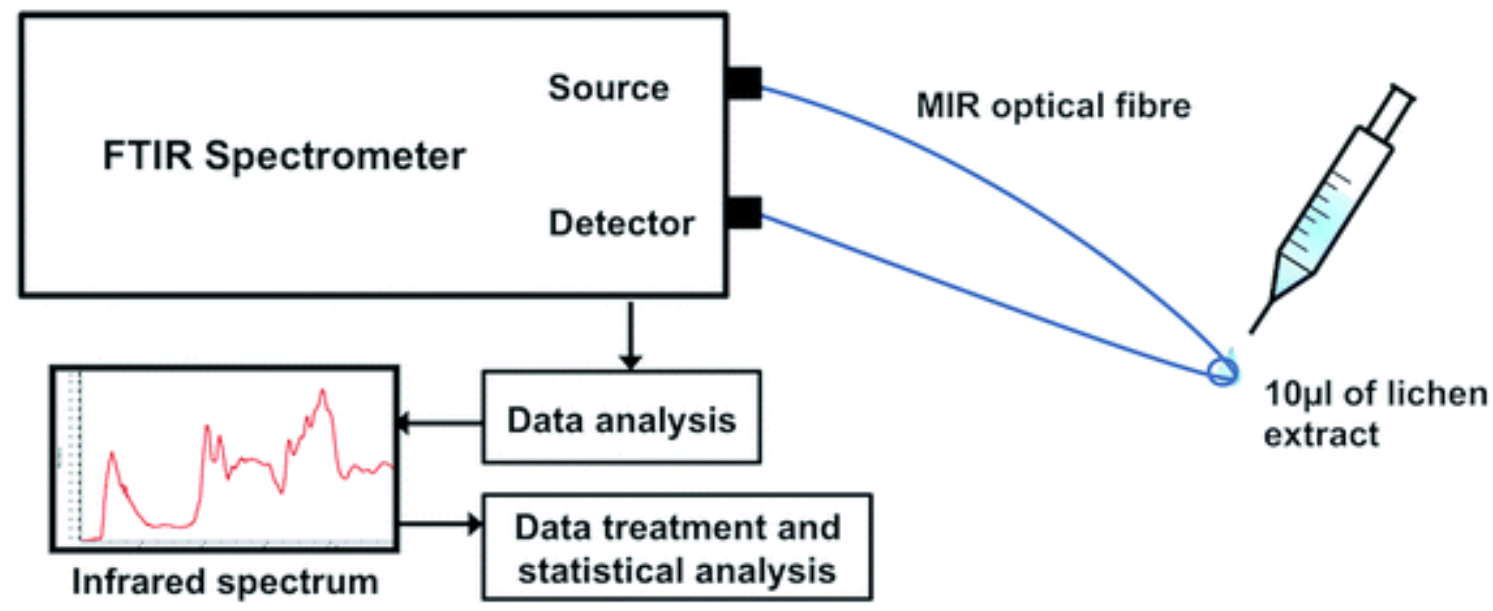

Fig. 1 Schematic representation of the experimental set-up used for recording the mid-infrared spectra. 


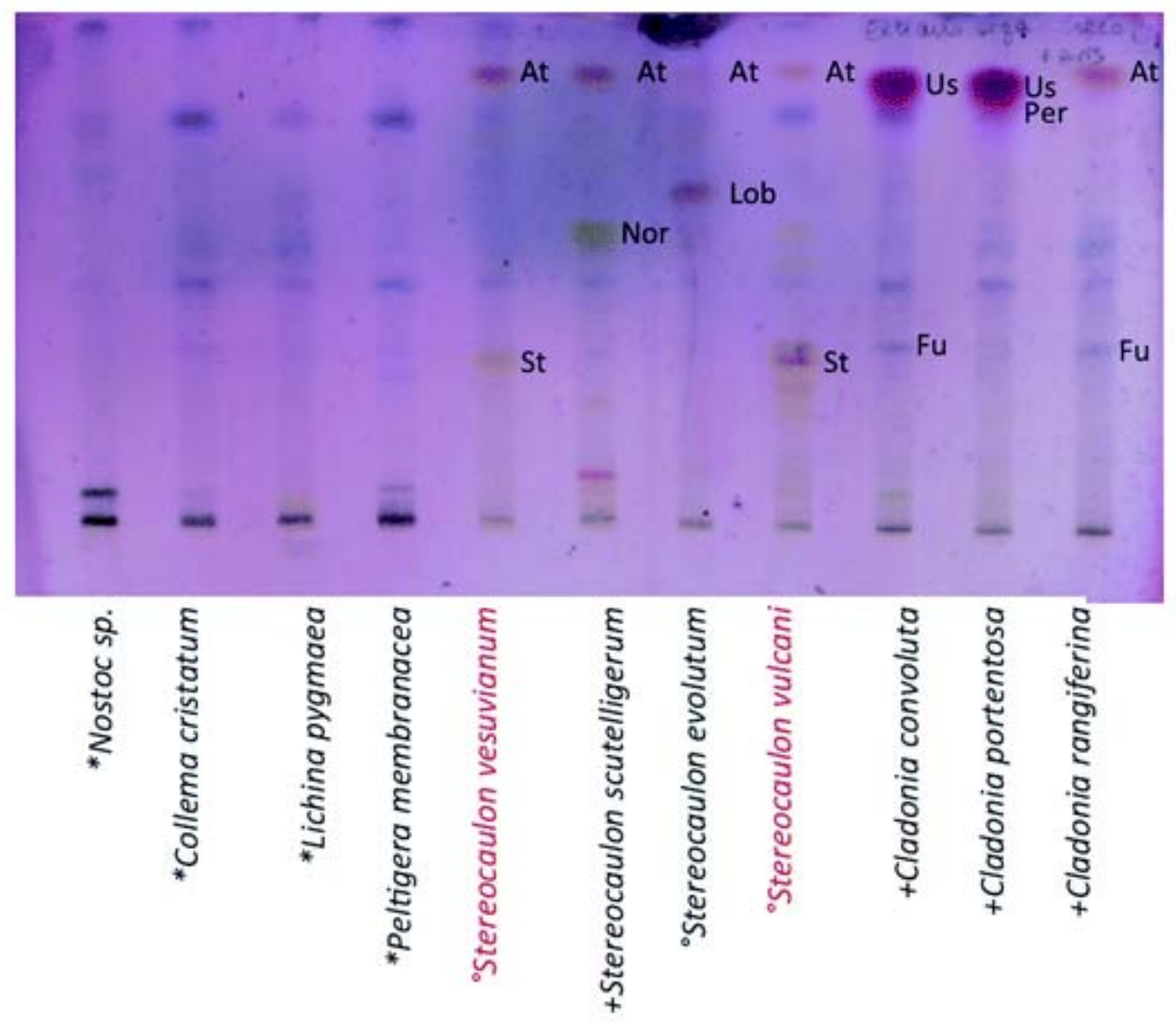

Fig. 2 TLC profile of the eleven organic samples in toluene/ethyl acetate/formic acid (139/83/8) after spraying sulfuric-anisaldehyde and heating. Major secondary metabolites have been identified with comparison with standards (At: atranorin; Fu:

fumarprotocetraric acid; Lob: lobaric acid; Nor: norstictic acid; Per: perlatolic acid; St: stictic acid; Us: usnic acid). ${ }^{*}$ Means that the lichens are belonging to the cyanolichens, ${ }^{\circ}=$ tripartite lichens, $+=$ chlorolichens.<smiles>COc1cc(C)c2c(c1C=O)Oc1c(C)c(O)c3c(c1OC2=O)C(O)OC3=O</smiles>

Stictic acid<smiles>CC(=O)c1c(C)cc(OC(=O)c2c(C)cc(O)c(C=O)c2O)c(C)c1O</smiles>

Atranorin<smiles>CC(=O)C1=C(O)C=C[C@@](C)(c2c(O)c(C)c(O)c(C(C)=O)c2O)C1=O</smiles>

Usnic acid

Fig. 3 Structure of the major compounds of S. vulcani, S. vesuvianum, Cladonia portentosa and Cladonia convoluta. 


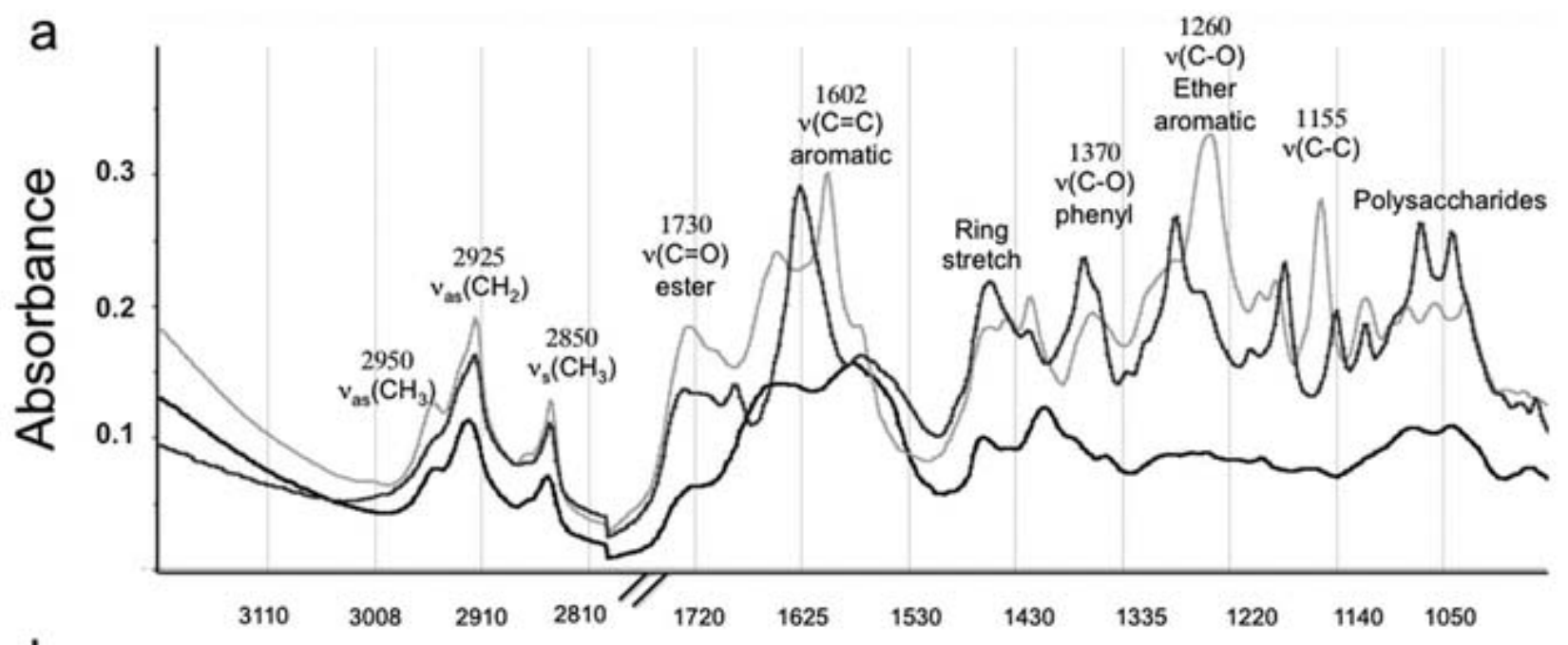

b

Wavenumbers $\left(\mathrm{cm}^{-1}\right)$

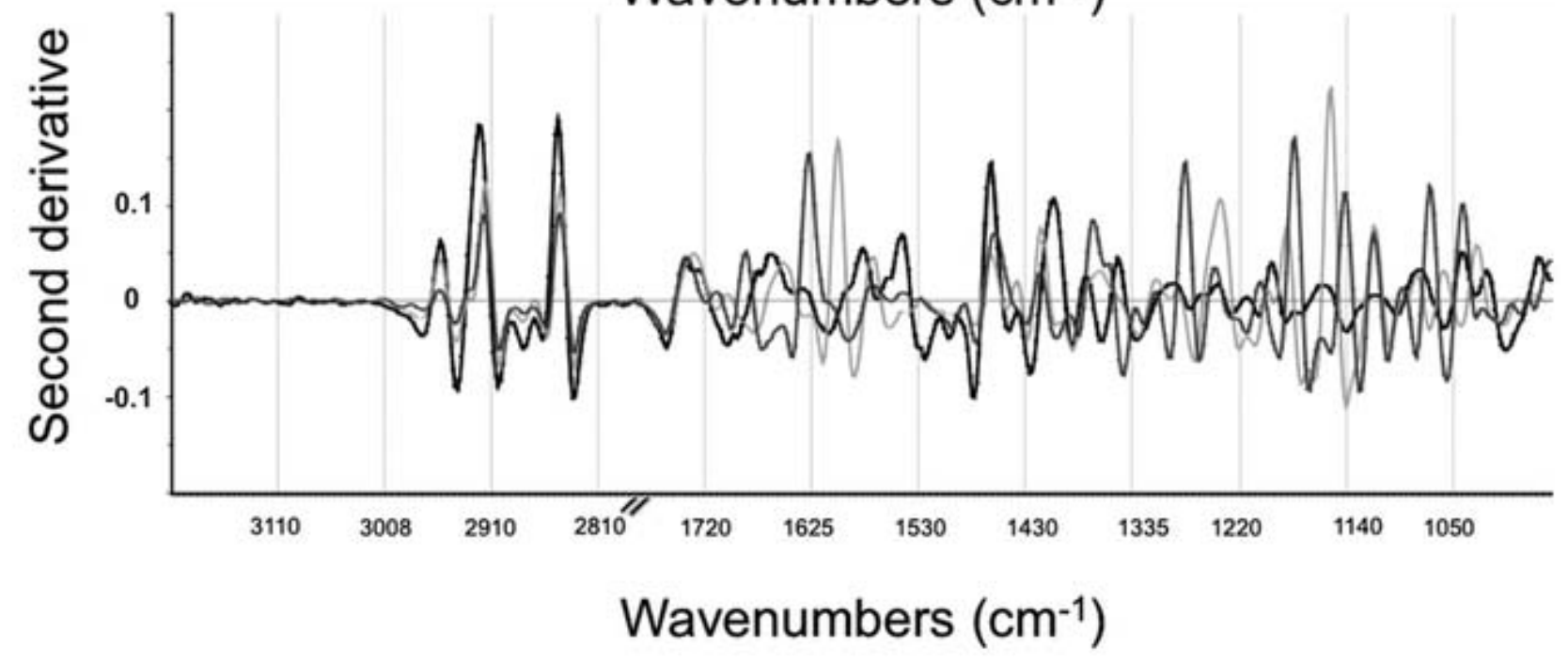

Fig. 4 (a) EMSC corrected infrared spectra in absorbance and (b) second derivative for 3 species. Lichina pygmaea (black), Cladonia convoluta (dark grey) and S. evolutum (light grey). 


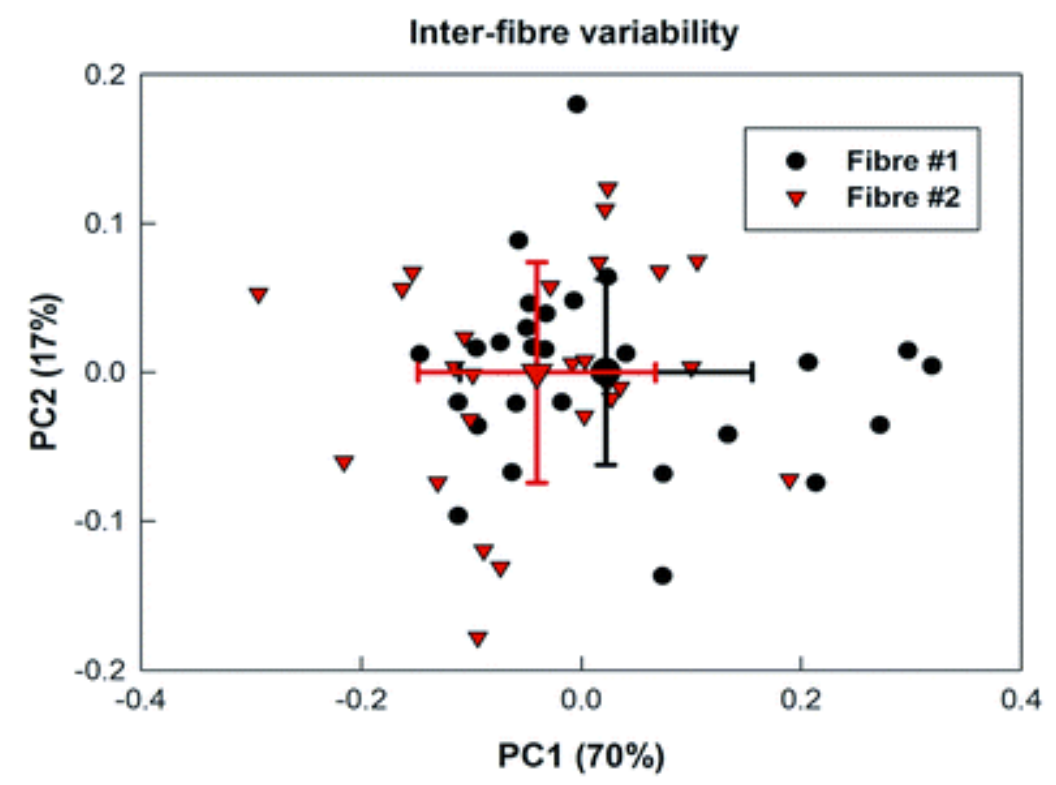

Fig. 5 PCA scores plot of second derivative spectra in the $1800-950 \mathrm{~cm}^{-1}$ domain for the interfibre variability evaluation. The barycentre was represented with cross. 